Copyright (C) 2021 by Cherkas Global University

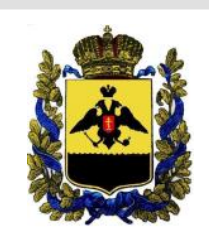

Published in the USA

Bylye Gody

Has been issued since 2006.

E-ISSN: $2310-0028$

2021. 16(4): 2043-2052

DOI: $10.13187 /$ bg.2021.4.2043

Journal homepage:

https://bg.cherkasgu.press

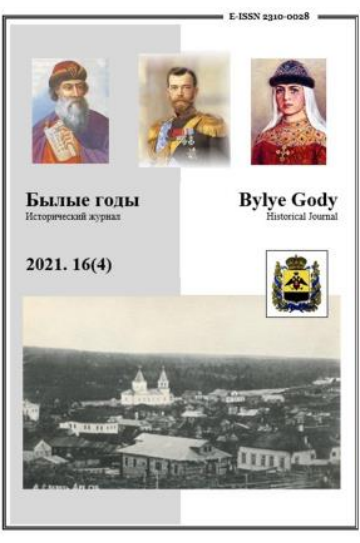

\title{
The Journal «Cine-phono» as a Historical Source: National Provincial Cinematography in 1907-1916
}

\author{
Natalia P. Koptseva a , ${ }^{*}$, Ksenia V. Reznikova a, Yulia N. Menzhurenko a \\ a Siberian Federal University, Russian Federation
}

\begin{abstract}
The article examines the possibilities of the materials of the journal "Cine-phono"to act as historical sources on the development of national cinema at the time of its formation. The discussions of the greatest interest for potential researchers, unfolding on its pages, were revealed: about the phenomenon of cinema, about its relationship with the authorities, about the reflection of the main current events in the development of cinematography, etc. by the residual principle. Analysis of the materials of the journal "Cine-phono" made it possible to single out in 1907-1916 three periods in the formation of provincial cinematography (19071908 cinematography mastered territories outside the boundaries of capital cities; in the 1909-1914s - active extensive development; decline in the number of references to provincial cities in 1915-1916 associated with the events of the First World War) and rank the regions depending on the level of development of cinematography. The most significant topics in the development of provincial cinema have been identified, these are general issues of the functioning of cinemas; political action in relation to cinema; education; emergencies; charity.
\end{abstract}

Keywords: journal “Cine-fono”, provincial cinema, 1907, education, Saratov.

\section{1. Введение}

Кинематограф как одно из наиболее популярных визуальных искусств в настоящее время представляет собой большой интерес для исследователей. Причем важными оказываются не только его актуальное состояние, но и историческое развитие, включая самые ранние этапы, что связано с возможностью проследить изменение его функций, осмысление его как феномена, его взаимоотношений с различными составляющими культуры. Журнал «Сине-фоно», вероятно, является одним из наиболее значимых источников для исследования отечественного кинематографа периода его становления, более того - одним из редчайших изданий, предпринимавших попытки зафиксировать и даже систематизировать бурное развитие отрасли не постфактум, но непосредственно в процессе не только в столицах, но и в провинциях.

\section{2. Материалы и методы}

Основным материалом для данной статьи выступил журнал «Сине-фоно»; всего было использовано 80 номеров 1907-1916 гг., в том числе для анализа материалов о провинциальном кинематографе в аспекте наиболее значимых городов были случайно отобраны по три номера ежегодно с 1908 по 1916 гг. включительно и два номера за 1907 г. - всего 29 номеров: 2-3 (1907); 5, 16, 20 (1908); 4, 6, 23 (1909); 2, 13, 24 (1910); 6, 12, 21 (1911); 7, 17, 24 (1912); 1, 4, 5 (1913); 9, 16, 20 (1914); 2, 9, 18 (1915); 1, 7, 8 (1916) - рубрик «Вести из городов», «Хроника» и «По городам и театрам». Для анализа материалов о провинциальном кинематографе в аспекте наиболее значимых событий -

\footnotetext{
${ }^{*}$ Corresponding author

E-mail addresses: decanka@mail.ru (N.P. Koptseva)
} 
69 номеров: 2-3 (1907); 2-9, 14-21 (1908); 3-6, 23-24 (1909); 2-3, 5-9, 13-24 (1910); 2-15 (1911); 7-8, 17-18 (1912); 1-2 (1913); 3, 7 (1914); 4, 8 (1915); 1, 8 (1916).

В качестве основных методов при работе над статьей выступили системный анализ и контентанализ. С помощью системного анализа, в фокусе которого находились постоянные рубрики журнала и статьи, появлявшиеся спорадически, на первом этапе удалось выделить представлявшие особый интерес в 1907-1916 гг. аспекты кинематографа. Сравнение объема рубрик и их расположения в журнале, а также анализ их жанровой строгости позволили сделать выводы о значимости каждой из них. На втором этапе применение контент-анализа позволило выделить наиболее значимые провинциальные города с точки зрения развития кинематографа. Длина списка провинциальных городов, попадавших в новостные сводки «Сине-фоно», менявшаяся от года к году, понималась как показатель интереса к провинциальному кинематографу в целом. Частота упоминаемости городов внутри отдельных регионов была соотнесена с исторической внутренней региональной иерархией. На третьем этапе исследования в качестве смысловых единиц были выбраны тематические блоки рубрики «Провинция», подсчет которых и объединение в укрупненные темы позволили выявить наиболее значимые события в провинциальной кинематографии.

\section{3. Обсуждение}

Значение российских средств массовой информации (газет и журналов) в качестве источника по истории Российской империи подчеркивается в ряде современных исследований (см., например, исследования М.А. Колесник, Н.М. Лещинской и Д.С. Пчелкиной (Колесник и др., 2021), Н.П. Копцевой, К.А. Дегтяренко, А.А. Шпак (Копцева и др., 2021). Взаимообусловленность национальной идентичности и развития различных видов искусств подчеркивается в работе Н.П. Копцевой, К.В. Резниковой и В.А. Разумовской (Koptseva et al., 2018). Эти два основания возможность рассматривать газеты и журналы как исторический источник, с одной стороны, и понимание базовой роли различных искусств в формировании чувства сопринадлежности к нации, народу, различным социально-культурным группам, с другой стороны, позволяют обосновать выбор темы исследования - отражение кинематографического искусства Российской империи в провинциальных средствах массовой информации.

До 1940-х гг. вопросы зарождения и раннего развития отечественного кинопроизводства в Российской империи трактовались в определенном мировоззренческом ключе. Художественнотворческий опыт кинематографистов дореволюционного периода не был отражен в литературе, и не было никакой документации, которая систематизировала бы историю отечественного кино. Одним из пионеров русского кинематографа был А.А. Ханжонков; он занимался созданием мемуаров, которые частично были опубликованы в работе «Первые годы русской кинематографии. Воспоминания» (Ханжонков, 1937) с ценнейшими примечаниями и фильмографией.

Советский киновед В.Е. Вишневский одним из первых занялся изучением дореволюционного кинонаследия, поставив перед собой задачу сохранить для последующих поколений в печатном виде многолетний опыт первого пятидесятилетия российского киноискусства ХХ в. Он составил фильмографическое описание «Художественные фильмы дореволюционной России» (Вишневский, 1945), где отразил все наиболее яркое и значительное для киноискусства того времени. Позднее C.С. Гинзбург выступил автором ряда научных работ и книжных изданий по кинематографу дореволюционной России (Гинзбург, 1963). Он занимался не только описанием фильмов и анализом их идейного содержания, но и предпринимал попытки выяснить, как отражались на киноискусстве события политической борьбы, как господствующие вкусы отпечатывались на тематике и стиле картин отечественного производства и как деятели кино использовали опыт старших искусств театра и литературы.

Крупнейший отечественный изобретатель в области кинотехники Е.М. Голдовский издал книгу «От немого кино к панорамному» (Голдовский, 1961), которая посвящена системам кинематографа, используемым при производстве и демонстрации фильмов различного жанра для кинотеатральной сети. Автор описывает путь развития советской кинотехники, принципы и технику панорамного, широкоэкранного и широкоформатного кинематографа, а также круговой кинопанорамы.

С начала XXI в. ученые продолжают изучать кинематограф Российской империи, кроме того, наблюдается рост интереса исследователей к проблеме регионального кинематографа в этот период. НИИ киноискусства ВГИК под руководством В.И. Фомина в рамках исполнения государственного контракта в 2012 г. сформировал отчет «История киноотрасли в России: управление, кинопроизводство, прокат» (Фомин, 2012), в котором проведен историко-сравнительный анализ целого комплекса наиболее важных и содержательных источников, отражающих развитие всех звеньев киноотрасли в их взаимодействии. Этот отчет стал своего рода информационным банком данных и документов по истории отечественной кинематографии и ее практической деятельности, начиная с дореволюционного периода и заканчивая современностью.

Исследователи рассматривают самые разные аспекты развития кинематографа в Российской империи. Е.А. Елисеева обращается к вопросу традиции решения экранного пространства, выявляя два его направления - «натурное» и «созданное», которые способствуют формированию 
определенного художественного образа и передаче его смысла (Елисеева, 2010). Насколько был успешен кинематограф Российской империи, а также историю международного сотрудничества в производстве кинофильмов, репертуары, способы воздействия на зрителей исследует М.И. Косинова (Косинова, 2013; 2015).

Н. Друбек, изучая данный период, выявляет две взаимосвязанные проблемы: зарождение русского кинематографа и природа возникновения киноцензуры. Анализируются примеры введения первоначального контроля над кино, коснувшегося не только иностранных фильмов, но и кинотехники, например, когда кинокамеры были не допущены в православный храм или когда были конфискованы кинокамеры с материалами, снятыми операторами компании «Люмьер» (Друбек, 2017).

М.А. Ростоцкая рассматривает роль конкретных личностей, который внесли значительный вклад в развитие кинематографа на ранних его этапах. Ею затрагиваются особенности кинематографа Якова Александровича Протазанова - кинорежиссера, сценариста и актера, который был глубоко укоренен в нравственную традицию русской культуры. Его кинокартины носили зрелищный характер и были популярны среди широкой зрительской аудитории (Ростоцкая, 2012). Еще одним ярким представителем российского кинематографа начала ХХ в. был Евгений Францевич Бауэр. Творчество этого выдающегося театрального художника, сценариста, режиссера немого кинематографа рассматривает М.А. Ростоцкая с нравственных позиций (Ростоцкая, 2011).

P.Н. Каукина, изучая этапы становления русского кинематографа, показывает, как стремительно новое чудо технического прогресса превращается в феномен эстетической, общественной, научной и экономической жизни Российской империи (Каукина, 2014). Л.В. Преснякова исследует проблемы взаимоотношений кинематографа и церкви в России первого десятилетия XX в. и делает вывод, что Русская православная церковь скорее отрицательно относилась к кинематографу, характеризуя его как явление, отвлекающее общество от христианской веры (Преснякова, 2009).

Среди исследователей, изучающих региональный кинематограф Российской империи, необходимо отметить В.А. Ватолина, Н.Н. Белякова, Т.С. Аверячкина, А.О. Ковалову, Г.Г. Гиберта, М.В. Александрову, Т.Г. Кузьмину, Е.А. Юнину, В.И. Елина и др. А.О. Ковалова обращается к вопросу кинопроизводства в Петербурге-Петрограде 1907-1917 гг., описывает петербургские кинофирмы, фильмографию, работу кинотеатров, вопросы сценирования (Ковалова, 2012; 2013 ). М.В. Александрова исследует деятельность ярославского кинопрокатчика и предпринимателя Г.И. Либкена, который основал ярославскую киностудию, функционировавшую в $1914-1917$ гг. (Александрова, 2017). Т.Г. Кузьмина посвящает свое исследование начальному этапу истории кино в г. Минусинске (Кузымина, 2016; Кузьмина, 2017). Взяв за основу ряд периодических изданий и документальные раритетные источники Российской империи, автор представляет ранее неизвестные фактологические данные. Особое внимание уделяется музыкальному сопровождению фильмов, выявляется тесная связь российского кинематографа с академической музыкальной культурой.

Е.А. Юнина изучает историю становления и процесс распространения стационарных синематеатров в городах Тобольской губернии, работая с архивными документами и осуществляя анализ региональной периодики (Юнина, 2021). Особое внимание уделяется административно-институциональному аспекту открытия электротеатров. Организация сети кинотеатров была связана с работой муниципальных органов власти, губернских учреждений, служащих полиции. Их функционирование подвергалось систематическому контролю чиновников, которые руководствовались принятыми в империи техническими нормативно-правовыми актами. В.И. Елин рассматривает историю развития кинематографического искусства в Самаре в начале XX в. (Елин, 2021).

\section{4. Результаты}

\section{1. Общая характеристика журнала «Сине-фоно»}

«Сине-фоно» издавался в 1907-1918 гг. в Москве С.В. Лурье дважды в месяц (в 1907 г. - 1-2 раза в месяц). Миссия журнала обозначена С.В. Лурье в обращении редактора в первом номере, датируемом 1 октября 1907 г., и состоит в обслуживании синематографа как отрасли промышленности, достигшей «высшего развития». Журнал призван не только заинтересовать синематографом даже тех, кто напрямую не связан с синематографией, но и постоянно обозначать ориентиры в бурно развивающемся новом виде искусства.

В «Сине-фоно» достаточно много места уделялось рекламам кинематографического и звукового оборудования, афишам и аннотациям новых фильмов, причем количество рекламного материала увеличивалось с течением времени. Так, если в № 2 за 1907 г. совокупно рекламные материалы занимают 11 полос из 18 (еще одна - титульная с названием журнала и его содержанием) - 61 \%, то в № 2 за 1911 г. - уже 45 из 62 (рекламной становится и титульная полоса) - 73 \%, а в № 8 за 1916 г. -128 из $162-79 \%$

Несмотря на значительную долю материалов коммерческого характера, «Сине-фоно» стал передовой площадкой для освещения кинематографа как важного феномена современной культуры. По составу материалов и рубрик можно судить о широком охвате различных аспектов кинематографа. Стабильно все номера журнала открывались словом редактора, поднимавшего наиболее 
злободневные темы. Большое внимание уделялось техническим вопросам кинематографии, объясняемым подробно и скрупулезно, например в статьях «Трансформаторы и мотор-генераторы для синематографических проекционных ламп» (1908, № 6); «Преобразование переменного тока в постоянный, с весьма незначительной потерей, по системе американца Купер-Юита» (1909, № 4) и др. Технические вопросы рассматривались не только теоретически: с 1908 г. постоянными стали рубрики, содержащие практические советы, - «Практические указания для демонстраторов», «Среди механиков» и т.п.

Без выделения в отдельную рубрику в каждом номере «Сине-фоно» присутствовали материалы, посвященные различным аспектам кинематографа как феномена культуры либо поискам сходств и отличий кинематографа от других видов искусств: «Синематограф как развлечение» (1907, № 2), «Художественная театральная постановка и синематограф» (1907, № 3), «Влияние синематографа на зрение» (1908, № 6). «Сине-фоно» стал рупором кинематографистов в сфере политики и обратной связью с властями: в нем публиковались проекты уставов, соглашений и правил, регулирующих функционирование кинематографа в различных его составляющих - «Правила, соблюдение коих необходимо при устройстве и содержании театров-синематографов в гор. Москве» (1908, № 21), «Устав Всероссийского Синематографического Общества» (1909, № 23) и т.д.

Для нашего исследования наибольший интерес представляют рубрики «Сине-фоно», содержащие материалы о состоянии провинциального кинематографа. В рассмотренных номерах журнала полностью отсутствуют рубрики с региональным содержанием (№ 1-2 1907 г. и № 4 в 1908 г.). В № 31907 г. появляются рубрики «Вести из городов» и «По театрам», с 1908 г. объединенные в «По городам и театрам», а также рубрика «Программы», сохранившаяся на протяжении всего рассматриваемого времени. С 1909 г. к имеющимся добавляется большой раздел «Хроника», в котором выделяются три крупных рубрики - «Москва», «Петербург» и «Провинция». Внутри «Провинции» практически во всех рассмотренных номерах (кроме № 4-6 за 1909 г. и 7-9 за 1910 г.) присутствует разделение на темы, в то время как в рубрике «По городам и театрам» разделение происходит только по населенным пунктам.

Среди всех названных отличается жесткой жанровой спецификой только рубрика «Программы», представляющая собой перечень городов и демонстрируемых на момент выхода журнала в них фильмов. Материалы для данной рубрики предоставляли в редакцию сами прокатчики. Три другие названные рубрики содержательно пересекаются между собой, но, тем не менее, позволяют опираться на материалы, в них содержащиеся, в качестве исторических источников. Помимо содержательного пересечения, обращает на себя внимание расположение рубрик: зачастую между «Хроникой» и «По городам и театрам» присутствует разделение материалами рубрик «Из заграничных журналов», «Письма в редакцию» и др. Разделение в подавляющем количестве номеров присутствует также и между рубриками «По городам и театрам» и «Программы».

Содержательные пересечения рубрик «Вести из городов», «По театрам», «Провинция», «По городам и театрам» и «Программы», их разбросанность по журналу, вероятно, указывают на то, что отношение к провинциальному кинематографу не было серьезным в издававшемся в Москве журнале. Столичные журналисты, кинематографисты не делали больших ставок на провинцию, развитие кинематографа в которой не шло уникальным путем, а скорее лишь отчасти копировало и то с опозданием столичные тенденции.

4.2. Анализ материалов о провинциальном кинематографе в «Сине-фоно»: наиболее значимые города

В рамках данного исследования в качестве значимых провинциальных городов в аспекте развития кинематографа принимались наиболее часто упоминаемые в региональных материалах «Сине-фоно» (за исключением рубрики «Программы»). Всего в проанализированных 29 номерах было упомянуто 146 оригинальных названий провинциальных населенных пунктов (учитывались только вошедшие в дальнейшем в состав РСФСР). Первые 10 мест по частоте встречаемости принадлежат следующим городам: Саратов (17 упоминаний); Вятка (15); Керчь (14); Пермь, Псков, Ростов-на-Дону, Сарапул (по 12); Красноярск, Нижний Новгород, Феодосия (по 11); Самара, Томск, Уфа (по 10); Воронеж, Казань, Симферополь (по 9); Вологда, Тула (по 8); Екатеринбург, Орел, Челябинск (по 7); Александровск, Владикавказ, Таганрог, Царицын (по 6). Наибольшее количество значимых для развития кинематографа провинциальных городов расположено, во-первых, на берегах Волги и ее притоках; во-вторых, в центральной части страны и в Крыму; в-третьих, в Сибири, на юге и северо-западе. В меньшей степени важными для развития кинематографа оказываются Урал, Кавказ, в то же время территории за Сибирью в перечень наиболее значимых городов не попали, хотя в «Сине-фоно» время от времени встречаются Владивосток и Хабаровск.

Интересным представляется обращение к динамике длины списка провинциальных населенных пунктов, оказывающихся на страницах «Сине-фоно». Так, в проанализированных номерах 1907 г. фигурировало только 9 оригинальных названий; в 1908 г. - 6; в 1909 г. - 35; в 1910 г. 43; в 1911 г. - 62; в 1912 г. - 42; в 1913 г. - 42 г.; в 1914 г. - 56; в 1915 г. - 14; в 1916 г. - 18. Данная динамика, вероятно, свидетельствует о том, что в 1907-1908 гг. кинематограф еще только осваивал 
территории за границами столичных городов, будучи одновременно дорогим по организации, но и потенциально крайне привлекательным для публики, а следовательно - рентабельным для владельцев. В 1909-1914-х гг. нетрудно заметить активное экстенсивное развитие - охват кинематографом все большего количества территорий. Спад количества упоминаний провинциальных городов в 1915-1916 гг. связан с событиями Первой мировой войны, начавшейся еще в 1914 г., влияние которой несколько с запозданием стало заметно в регионах.

Анализ частоты упоминаемости городов в «Сине-фоно» может быть рассмотрен через внутрирегиональную призму. В частности, можно сравнить, совпадает ли распределение губернских городов по значимости, зависящей от частоты упоминаемости в «Сине-фоно», с административнотерриториальной иерархией. Для примера можно остановиться на Енисейской губернии, частота упоминаний городов которой выглядит следующим образом: Енисейск - 1 (1912); Канск - 1 (1914); Красноярск - 2 (1909), 1 (1910), 2 (1911), 2 (1912), 1 (1913), 1 (1914), 2 (1915). Приведенное распределение свидетельствует о том, что кинематографическая жизнь в Красноярске была несравненно более активной, чем в столице губернии, что является свидетельством упадка Енисейска и возвышения роли Красноярска в начале XX в., обусловленных как экономическими, так и политическими причинами.

\section{3. Анализ материалов о провинциальном кинематографе в «Сине-фоно»: наиболее значимые темы}

Далее внимание будет сосредоточено на анализе и систематизации тематических блоков рубрики «Провинция», что позволит обнаружить основные наиболее значимые сферы культуры, связанные с провинциальным кинематографом 1907-1916 гг. Дальнейший анализ будет сосредоточен исключительно на названиях подрубрик внутри «Провинции», на количество упомянутых городов в той или иной из них, а также на принадлежность их к будущему РСФСР внимание обращаться не будет.

Анализ названий подрубрик «Провинции» позволяет сразу же отметить, что, во-первых, среди них присутствуют как постоянные, например «Новые театры», «Разное» и др.; так и встречающиеся единично, например «Бенефис механика» (1911, № 3), «Военный кинематограф» (1913, № 2), «Киноартель» (1913, № 1), «Просьба буфетчиков» (1914, № 7), «Скандал из-за шляпы» (1910, № 3) и др. Во-вторых, подрубрики, встречающиеся периодически, могут быть объединены в более крупные общие темы, к которым можно отнести и единичные новости. В-третьих, одной из популярнейших является подрубрика «Разное», в которую помещаются новости о провинциальном кинематографе, не подошедшие ни под одно из содержательных названий подрубрик, с одной стороны, и недостаточно интересные, чтобы для них была выделена отдельная подрубрика, с другой стороны. Фактически рубрика «По городам и театрам» представляет собой укрупненную подрубрику «Разное», с тем отличием, что в «По городам и театрам» даже не предпринимаются попытки систематизации новостей, хотя очевидно, что многие из них подходят под содержательные подрубрики «Провинции».

Наиболее частой по упоминаемости является тема, связанная с открытием, закрытием кинотеатров, сезонов и т.п., иначе - общие вопросы функционирования кинотеатров. В рассматриваемых номерах подрубрики, относимые к этой теме, встречаются 89 раз, в том числе «Новые театры» (в 41 номере), «Закрывшиеся театры» (в 15 номерах), «Проектируемые театры» (в 4), «Летний сезон» (в 3) и др. 2-е место по частоте встречаемости (35 раз) занимает тема просвещения, организуемого посредством кинематографа в провинции. Сюда относятся следующие подрубрики: «Разумный синематограф» (в 16 номерах), «Синематограф и учащиеся» (в 8), «Синематограф в школе» (в 4), «Научный синематограф» (в 3) и др. 3-е место - 33 раза - у темы чрезвычайных происшествий, как правило пожаров, случившихся от возгорания пленки: «Пожары» (в 26 номерах), «Вспыхнувшая лента» (в 2), «Смерть от ожогов» (в 1 номере) и др.

4-е место - 27 раз - политические действия в отношении кинематографа: «Действия администрации» (в 26 номерах), «Обязательные постановления» (в 1 номере), «Правила открытия синематографов» (в 1) и др. 5-е место - 23 раза - запреты: «Цензура» (в 11 номерах), «Запрещения аттракционных номеров» (в 3), «Запрещение посещать синематографы» (в 1), «Запрещение картины голода» (в 1 номере) и др. 6-е место - 19 раз - благотворительность: «Бесплатные сеансы» (в 8 номерах), «Благотворительные сеансы» (в 3), «Кинематографические сеансы для детей и нижних чинов» (в 1), «В пользу пострадавших от землетрясения» (в 1) и др. 7-е место - 10 раз - отражение актуальных событий: «В пользу голодающих» (в 3 номерах), «Отголосок землетрясения» (в 1), «На борьбу с чахоткой» (в 1), «Развлечения раненых» (в 1) и др.

На 8-м месте (по 9 раз) две темы - религиозные вопросы: «Синематографы накануне Успения» (в 1-м номере), «Синематограф на 4-ю неделю Великого поста» (в 1-м), «Синематограф рядом с церковью» (в 1-м), «Духовенство и иллюзионы» (в 1-м); и преступность: «Кража кинематографических фильмов» (в 1-м номере), «Подложное получение кинематографических картин» (в 1-м), «В судах» (в 1-м), «Злоупотребления благотворительными марками» (в 1-м) и др. 9-е место - 6 раз - сельский кинематограф: «Земский синематограф» (в 2 номерах), «Кинематограф в деревне» (в 2), «Кинематограф в уезде» (в 1), «Синематограф в селе» (в 1). 10-е место - 4 раза важные даты советской истории: «19 февраля и синематограф» (в 1-м номере), «Синематограф и торжество 19 февраля» (в 1-М), «19 февраля» (в 1-м), «К 1913 году» (в 1-м). Интересно, что тема 
религиозных праздников оказывается в рассматриваемый период более тесно связанной с кинематографом, чем торжеств, связанных со становлением нового советского государства.

Очевидно, что темы «Политические действия в отношении кинематографа» и «Запреты», занявшие 4-е и 5-е места соответственно, могут быть объединены, поскольку запреты, цензура являются вариантами политических действий. В таком случае эта укрупненная группа, встречающаяся в проанализированных номерах суммарно 50 раз, перемещается на 2-е место, и последовательность наиболее значимых новостных тем из сферы провинциальной кинематографии выглядят следующим образом: общие вопросы функционирования кинотеатров; политические действия в отношении кинематографа; просвещение; чрезвычайные ситуации; благотворительность.

\section{5. Заключение}

Проведенное исследование продемонстрировало крайнюю важность журнала «Сине-фоно» для осмысления становления и развития отечественного кинематографа на ранних этапах, поскольку в его материалах представлены дискуссии о функциях кинематографа, его технических особенностях, о взаимодействии кинематографа с властями и в целом - о кинематографе как феномене. Анализ материалов, посвященных провинциальному кинематографу, позволил обнаружить, что от него не ждали уникальных путей развития, внимание ему уделялось по остаточному принципу.

Анализ региональных материалов «Сине-фоно» позволил выделить 3 основных периода развития провинциального кинематографа в 1907-1916 гг.: в 1907-1908 гг. кинематограф осваивал территории за границами столичных городов; в 1909-1914-х гг. - активное экстенсивное развитие; спад количества упоминаний провинциальных городов в 1915-1916 гг. связан с событиями Первой мировой войны. Наибольшее количество значимых для кинематографа провинциальных городов располагалось в 1907-1916 гг. на берегах Волги и ее притоках; в центральной части страны и в Крыму; в Сибири, на юге и северо-западе.

Проведенное исследование позволило обнаружить, что провинциальный кинематограф в 19071916 гг. оказался крайне зависимым от политических сил: одни из наиболее значимых тем связаны с действиями местных администраций и с цензурой, запретами и прочими рамками, налагаемыми на кинематограф; в рассмотренный период кинематограф в регионах понимался как мощное средство просвещения; в силу своих технических особенностей в 1907-1916 гг. кинематограф представлял собой пожароопасное времяпрепровождение.

\section{6. Благодарности}

Исследование выполнено при финансовой поддержке РФФИ, Правительства Красноярского края и Красноярского краевого фонда науки в рамках научного проекта № 20-49-240001

\section{Литература}

Аверячкина, 2009 - Аверячкина T.C. Искусство кино в Забайкалье (по материалам забайкальской дореволюционной периодической печати // Наука и предпринимательство / Сборник научных статей преподавателей и аспирантов. Чита. 2009. С. 5-14.

Александров, 2020 - Александров E.B. Естествоиспытатели и научный кинематограф России в предреволюционный период (научный отдел фирмы А.А. Ханжонкова) // Жизнь Земли. 2020. Т. 42. № 3. С. $355-368$.

Александрова, 2017 - Александрова М.В. Пограничность творчества в провинции: Григорий Либкен и первые опыты ярославского кинематографа // Ярославский педагогцческий вестник. 2017. № 6. C. 309-313.

Алексеева, 2004 - Алексеева Е.П. Развитие и становление кинематографа в Казани и Казанской губернии (1897-1917 гг.): Автореф. дисс. ... канд. ист. наук / Казан. гос. ун-т культуры и искусств. Казань, 2004.

Белякова, 2008 -Белякова Н.Н. Кинематограф в дореволюционном Иркутске (1897-1917) // Вестник Новгородского государственного университета. 2008. № 49. С. 6-9.

Ватолин, 1998 - Ватолин B.A. Кинематограф в дореволюционной Сибири (история, место в жизни современников) (начало ХХ в.) // Музей и общество на пороге XXI в. Омск. 1998. С. 109-111.

Ватолин, 2002 - Ватолин B.A. Синема в Сибири: Очерки истории раннего сибирского кино (1896-1917) // Киноведческие записки. 2002. № 61. С. 359-379.

Вишневский, 1945 - Вишневский В.Е. Художественные фильмы дореволюционной России. М.: Госкиноиздат, 1945. 192 с.

Гиберт и др., 2016 - Гиберт Г.Г., Ныркова Д.А. Кавказ в дореволюционном документальном кино // Наследие веков. 2016. № 1 (5). С. 70-74.

Гинзбург, 2007 - Гинзбура С.С. Кинематография дореволюционной России. М.: Аграф. 2007.

Голдовский, 1962 - Голдовский E.M. От немого кино к панорамному. М.: Издательство Академии наук СССР. 1962. 149 с. 
Гращенкова и др., 2012 - Гращенкова И.Н., Зиборова О.П., Косинова М.Р., Фомин В.И. История киноотрасли в России: управление, кинопроизводство, прокат. М.: Всероссийский государственный институт кинематографии имени С.А. Герасимова. 2012. 2759 с.

Друбек, 2017 - Друбек Н. Рождение кино в Российской Империи и киноцензура // Вестник ВГИК. 2017. № 4 (34). С. 8-21.

Елин, 2021 - Елин В.И. Самарские театры и кинематограф в дореволюционный период // XXXVII зональная конференция литературоведов Поволжья / Сборник материалов Международной научно-практической конференции. Самара. 2021. С. 284-289.

Елисеева, 2010 - Елисеева E.A. «Натурное» и «Созданное» экранное пространство эпохи дореволюционного кино в России // Вестник Московского государственного университета культуры и искусств. 2010. № 6 (38). С. 212-218.

Иващенко, 2013 - Иващенко А.В. Начало научно-просветительского кинематографа в дореволюционной Самаре // Культурно-исторические исследования в Поволжье: проблемы и перспективы / Материалы II Всероссийского научно-методологического семинара. Самара, 2013. C. $75-80$.

Каукина, 2014 - Каукина Р.Н. Становление кинематографа в дореволюционной России (18961917 гг.) // Гуманитарные науки и образование. 2014. № 1 (17). С. 125-128.

Ковалова, 2012 - Ковалова А.О. Кинематограф в Петербурге (1907-1917). Кинопроизводство и фильмография. Энциклопедический отдел ИФИ Санкт-Петербургского государственного университета. СПб., 2012.

Ковалова, 2013 - Ковалова А.О. Сценарий в русском кино 1910-1920-х годов: к истории вопроса // Вестник Санкт-Петербургского университета. Искусствоведение. 2013. № 3. С. 33-47.

Косинова, 2013 - Косинова М.И. Кинопрокат и кинофикация в дореволюционной России (1896-1907) // Вестник ВГИК. 2013. № 17. С. 6-21.

Косинова, 2015 - Косинова М.И. Становление и развитие международных отношений в русской дореволюционной кинематографии // Мировая политика. 2015. № 1. С. 225-235.

Косых, 1988 - Косьх E.Н. Кинематограф дореволюционного Томска (1908 - октябрь 1917 гг.) // Из истории Томской области. Томск, 1988. С. 73-80;

Кузьмина, 2016 - Кузьмина Т.Г. Музыка и музыканты в дореволюционном кинематографе Минусинска // Союз искусства и науки / Материалы Международной научной конференции. Красноярск: Красноярский государственный институт искусств, 2016. С. 95-99.

Кузьмина, 2017 - Кузъмина Т.Г. Неизвестные страницы в истории дореволюционного кинематографа в Минусинске // Культура и цивилизация. 2017. Т. 7. № 1А. С. 556-562.

Лумпова, 2020 - Лумпова M.A. Становление феномена киноэкранизации (на примере дореволюционного кинематографа России) // Диалоги о культуре и искусстве / Maтериаль Х Всероссийской научно-практической конференции (с международным участием). Пермь, 2020. C. 351-359.

Миронов, 2013 - Миронов Г.А. Развитие кинодела в Среднем Поволжье в 1890-1930 гг.: историография проблемы // Исторические, философские, политические и юридические науки, культурология и искусствоведение. Вопросы теории и практики. 2013. № 12-2 (38). С. $137-141$.

Преснякова, 2009 - Преснякова Л.В. Церковь и кинематограф в дореволюционной России // Релиачоведение. 2009. № 3. С. 148-155.

Ростоцкая, 2011 - Ростоцкая М.A. Нравственные аспекты русского дореволюционного кинематографа. Евгений Бауэр // Вестник ВГИК. 2011. № 10. С. 8-17.

Ростоцкая, 2012 - Ростоцкая М.A. Нравственные аспекты русского дореволюционного кинематографа. Яков Протазанов // Вестник ВГИК. 2012. № 11. С. 6-15.

Русина, 2019 - Русина Ю.А. История советского кино. Екатеринбург: Изд-во Урал. ун-та, 2019. $104 \mathrm{c}$.

Ханжонков, 1937 - Ханжонков А.А. Первые годы русской кинематографии. Воспоминания. М.Л.: Государственное издательство «Искусство», 1937. 178 с.

Червяков, 2011 - Червяков С.Ю. Из опыта дореволюционной художественной культуры: кинематограф в Екатеринбурге конца XIX - начала XX вв. // 20 лет постсоветской России: кризисные явления и механизмы модернизации / Mатериалы XIV Всероссийской научно-практической конференции Гуманитарного университета. 2011. С. 267-270.

Юнина, 2021 - Юнина E.A. Процесс распространения и условия открытия стационарных кинотеатров в городах Тобольской губернии в начале XX века // Научный диалог. 2021. № 1. С. $451-471$.

Koptseva et al., 2018 - Koptseva N.P., Reznikova K.V., Razumovskaya, V.A. The construction of cultural and religious identities in the temple architecture // Journal of Siberian Federal University Humanities and Social Sciences. 2018. 11(7): 1021-1081.

Kolesnik et al., 2021 - Kolesnik M.A., Leshchinskaya N.M., Pchelkina D.S. "Yenisei Diocesan Gazette" as a source on the history of the peoples of the north of the Yenisei province of the late XIX - early XX centuries. Bylye Gody. 2021. 16(2): 889-897. 
Koptseva et al., 2021 - Koptseva N.P., Degtyarenko K.A., Shpak A.A. (2021). The Journal "Nature and People" (1910) as a Source on the History of the Peoples of the Russian Empire. Bylye Gody. 16(2): 990-999.

\section{References}

Aleksandrova, 2017 - Aleksandrova, M.V. (2017). Pogranichnost' tvorchestva v provincii: Grigorij Libken i pervye opyty yaroslavskogo kinematografa [Boundedness of creativity in the province: Grigory Libken and the first experiments of Yaroslavl cinematography]. Yaroslavsky pedagogichesky vestnik. 6: 309-313. [in Russian]

Alekseeva, 2004 - Alekseeva, E.P. (2004). Razvitie i stanovlenie kinematografa v Kazani i Kazanskoj gubernii (1897-1917 gg.) [Development and formation of cinematography in Kazan and the Kazan Province (1897-1917)]: avtoreferat dis. ... kandidata istoricheskih nauk. Kazan. gos. un-t kul'tury i iskusstv. Kazan'. [in Russian]

Alexandrov, 2020 - Alexandrov, E.V. (2020). Estestvoispytateli i nauchnyj kinematograf Rossii v predrevolyucionnyj period (nauchnyj otdel firmy A.A. Hanzhonkova) [Naturalists and scientific cinematography in Russia in the pre-revolutionary period (A.A. Khanzhonkov's scientific department)]. Zhizn' Zemli. 42(3): 355-368. [in Russian]

Averyachkina, 2009 - Averyachkina, T.S. (2009). Iskusstvo kino v Zabajkal'e (po materialam zabajkal'skoj dorevolyucionnoj periodicheskoj pechati) [Art of cinema in Transbaikalia (on materials of Transbaikalian pre-revolutionary periodicals]. Nauka i predprinimatel'stvo. Chita, Pp. 5-14. [in Russian]

Belyakova, 2008 - Belyakova, N.N. (2008). Kinematograf v dorevolyucionnom Irkutske (1897 - 1917) [Cinematography in pre-revolutionary Irkutsk (1897 - 1917)]. Vestnik Novgorodskogo gosudarstvennogo universiteta. 49: 6-9. [in Russian]

Chervyakov, 2011 - Chervyakov, S.Y. (2011). Iz opyta dorevolyucionnoj hudozhestvennoj kul'tury: kinematograf $\mathrm{v}$ Ekaterinburge konca XIX - nachala XX vv. [From the experience of pre-revolutionary artistic culture: cinematography in Yekaterinburg in the late 19th - early 20th centuries]. 20 let postsovetskoj Rossii: krizisnye yavleniya i mekhanizmy modernizacii. Materialy XIV Vserossijskoj nauchno-prakticheskoj konferencii Gumanitarnogo universiteta. Ekaterinburg, pp. 267-270. [in Russian]

Droubek, 2017 - Droubek, N. (2017). Rozhdenie kino v Rossijskoj Imperii i kinocenzura [The birth of cinema in the Russian Empire and censorship]. Vestnik Vserossijskogo gosudarstvennogo universiteta kinematografii. 4 (34): 8-21. [in Russian]

Eliseeva, 2010 - Eliseeva, E.A. (2010). "Naturnoe" i "Sozdannoe" ekrannoe prostranstvo epohi dorevolyucionnogo kino v Rossii ["Natural" and "Created" screen space of pre-revolutionary cinema era in Russia]. Vestnik Moskovskogo gosudarstvennogo universiteta kul'tury i iskusstv. 6(38): 212-218. [in Russian]

Gibert et al, 2016 - Gibert, G.G., Nyrkova, D.A. (2016). Kavkaz v dorevolyucionnom dokumental'nom kino [The Caucasus in pre-revolutionary documentary cinema]. Nasledie vekov. 1(5): 70-74. [in Russian]

Ginzburg, 2007 - Ginzburg, S.S. (2007). Kinematografiya dorevolyutsionnoi Rossii [Cinematography of pre-revolutionary Russia]. Moscow: Agraf. [in Russian]

Goldovsky, 1962 - Goldovsky, E.M. (1962). Ot nemogo kino k panoramnomu [From silent cinema to panoramic cinema]. Moscow: Publishing House of the Academy of Sciences of the USSR. 149 p. [in Russian]

Grashchenkova et al., 2012 - Grashchenkova, I.N., Ziborova, O.P., Kosinova, M.R., Fomin, V.I. (2012)

Istoriya kinootrasli $\mathrm{v}$ Rossii: upravlenie, kinoproizvodstvo, prokat [History of the film industry in Russia: management, film production, distribution]. Moscow: All-Russian State Institute of Cinematography named after S. A. Gerasimov, 2759 p. [in Russian]

Ivashchenko, 2013 - Ivashchenko, A.V. (2013). Nachalo nauchno-prosvetitel'skogo kinematografa v dorevolyucionnoj Samare [The beginning of scientific and educational cinematography in pre-revolutionary Samara]. Kul'turno-istoricheskie issledovaniya $v$ Povolzh'e: problemy $i$ perspektivy. Materialy II Vserossijskogo nauchno-metodologicheskogo seminara. Samara, pp. 75-80. [in Russian]

Kaukina, 2014 - Kaukina, R.N. (2014). Stanovlenie kinematografa v dorevolyucionnoj Rossii (18961917 gg.) [Formation of cinematography in pre-revolutionary Russia (1896-1917)]. Gumanitarnye nauki $i$ obrazovanie. 1(17): 125-128. [in Russian]

Khanzhonkov, 1937 - Khanzhonkov, A.A. (1937). Pervye gody russkoj kinematografii. Vospominaniya [The first years of Russian cinematography. Memories]. Moscow-Leningrad: The State Publishing House "Art". 178 p. [in Russian]

Kolesnik et al., 2021 - Kolesnik, M.A., Leshchinskaya, N.M., Pchelkina, D.S. (2021). "Yenisei Diocesan Gazette" as a source on the history of the peoples of the north of the Yenisei province of the late XIX - early XX centuries. Bylye Gody. 16(2): 889-897.

Koptseva et al., 2018 - Koptseva, N.P., Reznikova, K.V., Razumovskaya, V.A. (2018). The construction of cultural and religious identities in the temple architecture. Journal of Siberian Federal University - Humanities and Social Sciences. 11(7): 1021-1081.

Koptseva et al., 2021 - Koptseva, N.P., Degtyarenko, K.A., Shpak, A.A. (2021). The Journal "Nature and People" (1910) as a Source on the History of the Peoples of the Russian Empire. Bylye Gody. 16(2): 990-999. 
Kosinova, 2013 - Kosinova, M.I. (2013). Kinoprokat i kinofikaciya v dorevolyucionnoj Rossii (18961907) [Film distribution and cinematography in pre-revolutionary Russia (1896-1907)]. Vestnik Vserossijskogo gosudarstvennogo universiteta kinematografii. 17: 6-21. [in Russian]

Kosinova, 2015 - Kosinova, M.I. (2015). Stanovlenie i razvitie mezhdunarodnyh otnoshenij v russkoj dorevolyucionnoj kinematografii [Formation and development of international relations in the Russian prerevolutionary cinema]. Mirovaya politika. 1: 225-235. [in Russian]

Kosykh, 1988 - Kosykh, E.N. (1988). Kinematograf dorevolyucionnogo Tomska (1908 - oktyabr' 1917 gg.) [Cinematography of pre-revolutionary Tomsk (1908 - October 1917)]. From the history of the Tomsk region. Tomsk, pp. 73-80. [in Russian]

Kovalova, 2012 - Kovalova, A.O. (2012). Kinematograf v Peterburge (1907-1917). Kinoproizvodstvo i fil'mografiya. Enciklopedicheskij otdel IFI Sankt-Peterburgskogo gosudarstvennogo universiteta. [Cinematography in St. Petersburg (1907-1917). Film production and filmography. Encyclopedic Department of the IPhI of St. Petersburg State University]. St. Petersburg. [in Russian]

Kovalova, 2013 - Kovalova, A.O. (2013). Scenarij v russkom kino 1910-1920-h godov: k istorii voprosa [Screenplay in Russian cinema in 1910-1920s: to the history of the question]. Vestnik SanktPeterburgskogo universiteta. Iskusstvovedenie. 3: 33-47. [in Russian]

Kuzmina, 2016 - Kuzmina, T.G. (2016). Muzyka i muzykanty v dorevolyucionnom kinematografe Minusinska [Music and musicians in the pre-revolutionary cinematography of Minusinsk]. Soyuz iskusstva $\mathrm{i}$ nauki. Krasnoyarsk: Krasnoyarskii gosudarstvennyi institut iskusstv, pp. 95-99. [in Russian]

Kuzmina, 2017 - Kuzmina, T.G. (2017). Neizvestnye stranicy v istorii dorevolyucionnogo kinematografa $\mathrm{v}$ Minusinske [Unknown pages in the history of pre-revolutionary cinema in Minusinsk]. Kul'tura i civilizaciya. 7(1a): 556-562. [in Russian]

Lumpova, 2020 - Lumpova, M.A. (2020). Stanovlenie fenomena kinoekranizacii (na primere dorevolyucionnogo kinematografa Rossii) [Formation of the phenomenon of film screening (on the example of pre-revolutionary cinematography in Russia)]. Dialogi o kul'ture $i$ iskusstve. Materialy X Vserossijskoj nauchno-prakticheskoj konferencii (s mezhdunarodnym uchastiem). Perm, pp. 351-359. [in Russian]

Mironov, 2013 - Mironov, G.A. (2013). Razvitie kinodela v Srednem Povolzh'e v 1890-1930 gg.: istoriografiya problemy [Development of cinema in the Middle Volga region in 1890-1930: historiography of the problem]. Istoricheskie, filosofskie, politicheskie i yuridicheskie nauki, kul'turologiya i iskusstvovedenie. Voprosy teorii i praktiki. 12-2 (38): 137-141. [in Russian]

Presnyakova, 2009 - Presnyakova, L.V. (2009). Tserkov' i kinematograf v dorevolyucionnoj Rossii [Church and Cinematography in Pre-Revolutionary Russia]. Religiovedenie. 3: 148-155. [in Russian]

Rostotskaya, 2011 - Rostotskaya, M.A. (2011). Nravstvennye aspekty russkogo dorevolyucionnogo kinematografa. Evgenij Baue [Moral aspects of Russian pre-revolutionary cinema. Evgeny Bauer]. Vestnik Vserossijskogo gosudarstvennogo universiteta kinematografii. 10: 8-17. [in Russian]

Rostotskaya, 2012 - Rostotskaya, M.A. (2012). Nravstvennye aspekty russkogo dorevolyucionnogo kinematografa. Yakov Protazanov [Moral aspects of Russian pre-revolutionary cinema. Yakov Protazanov]. Vestnik Vserossijskogo gosudarstvennogo universiteta kinematografii. 11: 6-15. [in Russian]

Rusina, 2019 - Rusina, Yu.A. (2019) Istoriya sovetskogo kino [History of Soviet cinema]. Yekaterinburg: Izd-vo Ural. un-ta. 104 p. [in Russian]

Vatolin, 1998 - Vatolin, V.A. (1998). Kinematograf v dorevolyucionnoj Sibiri (istoriya, mesto v zhizni sovremennikov) (nachalo XX v.) [Cinematography in pre-revolutionary Siberia (history, place in the life of contemporaries) (early XX century)]. Muzej i obshchestvo na poroge XXI v. Omsk, pp. 109-111. [in Russian]

Vatolin, 2002 - Vatolin, V.A. (2002). Sinema v Sibiri: Ocherki istorii rannego sibirskogo kino (18961917) [Cinema in Siberia: Essays on the history of early Siberian cinema (1896-1917)]. Kinovedcheskie zapiski. 61: 359-379. [in Russian]

Vishnevsky, 1945 - Vishnevsky, V.E. (1945). Hudozhestvennye fil'my dorevolyucionnoj Rossii [Art films of pre-revolutionary Russia]. Moscow: Goskinoizdat. 192 p. [in Russian]

Elin, 2021 - Yelin, V.I. (2021). Samarskie teatry i kinematograf v dorevolyucionnyj period [Samara theaters and cinematography in the pre-revolutionary period]. XXXVII zonal'naya konferenciya literaturovedov Povolzh'ya. Sbornik materialov Mezhdunarodnoj nauchno-prakticheskoj konferencii. Samara, pp. 284-289. [in Russian]

Yunina, 2021 - Yunina, E.A. (2021) Process rasprostraneniya i usloviya otkrytiya stacionarnyh kinoteatrov v gorodah Tobol'skoj gubernii v nachale XX veka [Process of distribution and conditions of opening of stationary cinemas in the Tobolsk Province towns at the beginning of XX century]. Nauchnyj dialog. 1: 451-471. [in Russian] 
Журнал «Сине-фоно» как исторический источник: отечественный провинциальный кинематограф в 1907-1916 гг.

\author{
Наталья Петровна Копцева ${ }^{a},{ }^{*}$, Ксения Вячеславовна Резникова а, Юлия Николаевна Менжуренко а \\ a Сибирский федеральный университет, Российская Федерация
}

Аннотация. В статье изучаются возможности материалов журнала «Сине-фоно» выступать в качестве исторических источников по вопросу развития отечественного кинематографа времени его становления. Выявлены представляющие наибольший интерес для потенциальных исследователей дискуссии, разворачивающиеся на его страницах: о феномене кинематографа, о его взаимоотношениях с властью, об отражении в развитии кинематографа основных актуальных событий и др. Обнаружено, что от провинциального кинематографа не ждали уникальных путей развития, внимание ему уделялось по остаточному принципу. Анализ материалов журнала «Синефоно» позволил выделить в 1907-1916 гг. три периода в становлении провинциального кинематографа (1907-1908 гг. кинематограф осваивал территории за границами столичных городов; в 1909-1914-х гг. - активное экстенсивное развитие; спад количества упоминаний провинциальных городов в 1915-1916 гг. связан с событиями Первой мировой войны) и проанализировать регионы в зависимости от уровня развития кинематографии. Установлены наиболее значимые темы в развитии провинциального кинематографа: это общие вопросы функционирования кинотеатров, политические действия в отношении кинематографа, просвещение, чрезвычайные ситуации, благотворительность.

Ключевые слова: журнал «Сине-фоно», провинциальный кинематограф, 1907 год, просвещение, Саратов.

\footnotetext{
${ }^{*}$ Корреспондирующий автор

Адреса электронной почты: decanka@mail.ru (Н.П. Копцева) 